\title{
Soy Milk as a Storage Medium to Preserve Human Fibroblast Cell Viability: An In Vitro Study
}

\author{
Camilla Christian Gomes MOURA ${ }^{1}$ \\ Priscilla Barbosa Ferreira SOARES ${ }^{2}$ \\ Manuella Verdinelli de Paula REIS ${ }^{1}$ \\ Alfredo Júlio FERNANDES NETO ${ }^{3}$ \\ Carlos José SOARES ${ }^{1}$
}

\author{
${ }^{1}$ Department of Operative Dentistry and Dental Materials, Dental School, \\ UFU - Federal University of Uberlândia, Uberlândia, MG, Brazil \\ ${ }^{2}$ Department of Periodontology and Implantology, Dental School, \\ UFU - Federal University of Uberlândia, Uberlândia, MG, Brazil \\ ${ }^{3}$ Department of Occlusion and Prosthodontics, Dental School, \\ UFU - Federal University of Uberlândia, Uberlândia, MG, Brazil
}

\begin{abstract}
Soy milk (SM) is widely consumed worldwide as a substitute for cow milk. It is a source of vitamins, carbohydrates and sugars, but its capacity to preserve cell viability has not been evaluated. The purpose of the present study was to investigate the efficacy of SM to maintain the viability of human fibroblasts at short periods compared with different cow milks. Human mouth fibroblasts were cultured and stored in the following media at room temperature: 10\% Dulbecco's Modified Eagle Medium (DMEM) (positive control group); long shelf-life ultra-high temperature whole cow milk (WM); long shelf-life ultra-high temperature skim cow milk (SKM); powdered cow milk (PM); and soy milk (SM). After 5, 15, 30 and $45 \mathrm{~min}$, cell viability was analyzed using the MTT assay. Data were analyzed statistically by the Kruskal-Wallis test with post-analysis using the Dunn's method ( $\alpha=0.05)$. SKM showed the lowest capacity to maintain cell viability in all analyzed times $(\mathrm{p}<0.05)$. At 30 and $45 \mathrm{~min}$, the absorbance levels in control group (DMEM) and SM were significantly higher than in SKM $(\mathrm{p}<0.05)$. Cell viability decreased along the time $(5-45 \mathrm{~min})$. The results indicate that $\mathrm{SM}$ can be used as a more adequate storage medium for avulsed teeth. SKM was not as effective in preserving cell viability as the cell culture medium and SM.
\end{abstract}

Key Words: avulsed teeth, soy milk, fibroblast cells, storage media.

\section{INTRODUCTION}

Mature tooth avulsion results in attachment damage and pulp necrosis $(1,2)$. Ideally, the tooth should be replanted immediately after the injury $(1,3)$. Unfortunately, immediate repositioning of the tooth is not always possible $(3,4)$. In such situations, the prognosis is strongly influenced by extraoral drying time and by the transportation medium (5). Transportation in wet physiological media prevents the desiccation of periodontal cells, which reduces the cell damage (1) and prevents ankylosis and replacement resorption (6).
The capacity of the storage medium to maintain periodontal ligament cell viability may be even more important to tooth replantation than the extraoral period (7). Several materials have been studied as to their ability to support the viability of periodontal ligament cells and thus to permit delayed replantation (8-10). Milk (10-14), Hank's balanced saline solution (8-10,15), propolis $(16)$ and coconut water $(8-10,17)$ are frequently recommended. However, the ideal solution to tooth storage must be readily accessible in locations in which tooth avulsion is likely to occur $(4,10)$. Cow milk may be considered the best alternative among the storage

Correspondence: Prof. Dr. Carlos José Soares, Área de Dentística e Materiais Odontológicos, Faculdade de Odontologia, Universidade Federal de Uberlândia, Av. República do Piratini, Sem Número, Bloco 4L, Anexo A, Sala 4LA32, Campus Umuarama, 38400-902 Uberlândia, MG, Brasil.Tel: +55-34-3218-2255. Fax: +55-34-3218-2279. e-mail: carlosjsoares@umuarama.ufu.br 
media that are easily available at the site of an accident $(8,9,18)$. This solution provides nutritive substances that are able to nourish the cells $(18,19)$, such as amino acids, carbohydrates and growth factors (20), a neutral $\mathrm{pH}$ and physiological osmolality $(18,19)$. Although several studies have been conducted evaluating the cow milk as a storage medium $(10-14,18)$, the potential use of soy milk for tooth storage has been poorly evaluated (21). Whereas a growing number of people are using this alternative to cow milk, which reflects an increase in its accessibility, this study evaluated a milk-like soy beverage compared with whole cow milk, skim cow milk and powdered cow milk regarding their ability to preserve fibroblasts. The null hypothesis was that soy milk is as effective as cow milk for preservation of fibroblast cell viability.

\section{MATERIAL AND METHODS}

Immortalized human mouth fibroblasts (Cell Bank of Rio de Janeiro, Rio de Janeiro, RJ, Brazil) were cultured in T-25 cell culture flasks containing Dulbecco's Modified Eagle Medium (DMEM) (Sigma Chemical Co., St. Louis, MO, USA) supplemented with $10 \%$ fetal calf serum (Invitrogen, Branchburg, NJ, USA), 100 units $\mathrm{mL}^{-1}$ of penicillin/streptomycin (Sigma Chemical Co.) in a humidifier incubator with $5 \% \mathrm{CO}_{2}$ and $95 \%$ air at $37^{\circ} \mathrm{C}$. Growth was permitted until the cells achieved confluence. These cells were detached, counted using a hemocytometer and plated in 96-well plates (Coastar Corp., Cambridge, MA, USA) at an initial density of $1 \times 10^{4}$ cells.well $^{-1}$ in $100 \mu \mathrm{L}$ of culture medium. The plates were returned to the incubator for 24 h. Subsequently, the culture medium was drained from each well and the cells were exposed to $100 \mu \mathrm{L}$ of the different experimental solutions at room temperature for $5,15,30$ and $45 \mathrm{~min}$. The storage solutions used in the experiments were one soy milk fortified with vitamins - SM (Sollys Original; Nestlé, Araras, SP, Brazil) and three presentations of cow milk: long shelf-life ultra-high temperature whole milk - WM (Italac Integral; Italac, Corumbaíba, GO, Brazil); long shelf-life ultra high temperature skim milk - SKM (Italac Desnatado; Italac) and powdered milk - PM (Molico; Nestlé, Araçatuba, SP, Brazil). The positive control corresponded to cells maintained in 10\% DMEM, without additional treatment. After the experimental times ran out, the storage solutions were replaced by $10 \%$ DMEM and incubated with MTT solution ( $\left.5 \mathrm{mg} . \mathrm{mL}^{-1}\right)$ prior to cell viability evaluation. The same protocol was used for the positive control group (DMEM). After $4 \mathrm{~h}$, the MTT solution was removed and $100 \mu \mathrm{L}$ of dimethyl sulfoxide (Sigma Chemical Co.) were added to each well. Cell viability was determined by measuring the optical density at 540 $\mathrm{nm}$ on a microplate reader. The experiment was done in quadruplicate on two different days, with 10 samples per group. The absolute values of absorbance obtained from each well for each group at all experimental times were subjected to analysis of normality. Data were analyzed statistically by Kruskal-Wallis and Dunn's test at a 5\% significance level.

\section{RESULTS}

The absorbance values, which represent fibroblast cell viability for each tested medium and for each tested period are shown in Figure 1. There were time-dependent results according to the analyzed experimental solution. SKM had the lowest capacity to maintain cell viability in all analyzed times $(p<0.05)$. At $5 \mathrm{~min}$, SKM had lower indices of absorbance than the PM and the control group $(\mathrm{DMEM})(\mathrm{p}=0.001$, Fig. 1A). At $15 \mathrm{~min}$, SKM remained as the worst analyzed storage solution, with absorbance rates lower than the WM, SM and control group (DMEM) $(p=0.020$, Fig. 1B). Even though at 30 and $45 \mathrm{~min}$ the cells preserved in SKM showed viability comparable to that of PM and WM ( $>00.05)$, its absorbance indices were inferior to those of the SM and control group (DMEM) (30 min, $p=0.006 ; 45 \mathrm{~min}, \mathrm{p}=0.001$, Fig. $1 \mathrm{C}$ and Fig. $1 \mathrm{D}$, respectively). Although there is a tendency to reduce the levels of absorbance presented in each group over time, there were no significant differences in viability rates between 5 and $45 \mathrm{~min}$ for each storage solution (WM, $\mathrm{p}=0.154 ;$ SKM, $\mathrm{p}=0.270 ; \mathrm{PM}, \mathrm{p}=0.070 ; \mathrm{SM}, \mathrm{p}=0.241$ ).

\section{DISCUSSION}

In the current study, the null hypothesis was rejected. SM was able to preserve fibroblast cell viability, showing similar results to those of the control group (DMEM culture medium), cow milk and PM. The potential benefits of SM as a storage medium for avulsed teeth has recently been demonstrated. In agreement with the present study, Moazami et al. (21) showed that HBSS, powdered baby formula and SM maintained equally the cell viability. Despite the similar results, it is important to address the differences of the cell culture model, the method used for viability analysis, type of 
soy powered milk used and periods of evaluation. The improved viability of cells stored in SM may be due to the cytoprotective effects of nutrient constituents such as carbohydrates, sugars, proteins, fats, calcium, vitamins $\mathrm{A}, \mathrm{C}, \mathrm{D}$ and $\mathrm{E}$, as well as the physiological $\mathrm{pH}$. Such components may help nourishing the cells and maintaining their viability, which makes SM an alternative to other milk formulations as a storage medium. There is strong evidence that milk effectively maintains the viability of periodontal ligament cells $(6,11-14,18)$. However, concern has been raised over its temperature $(4,6,11)$ and fat content $(4,12)$.

Avulsed teeth are normally stored in a medium at room temperature (10), although some studies suggest better results when they are stored in chilled milk $(6,11,22)$. The current study was performed at room temperature to reproduce the clinical conditions. Regarding the fat content, a previous study indicated that milk with a lower fat content might be more appropriate for maintaining cell viability than whole milk, which has a higher fat content (12). However, in the present study, there was no significant difference between WM and SKM. The lack of difference between the groups maintained in WM and SM might be related to the experimental design, the type of milk and the temperature of the milk. Interestingly, the milk with a lower fat content presented worse results compared with SM and the positive control (DMEM). Given these results, it may be speculated that the reduction in fat and carbohydrates during the production of SKM reduced its capacity to nourish the cells.

This study also investigated powdered milk, which presented good results when compared with the long shelf-life milks. Similar results have been reported elsewhere $(14,21,23)$, but differences in cell type and experiment design do not allow direct comparisons. Despite PM potential as a storage media, the favorable results obtained with SM, were a point of great interest in the present study. This soy-based drink enriched with vitamins represents a promising alternative for
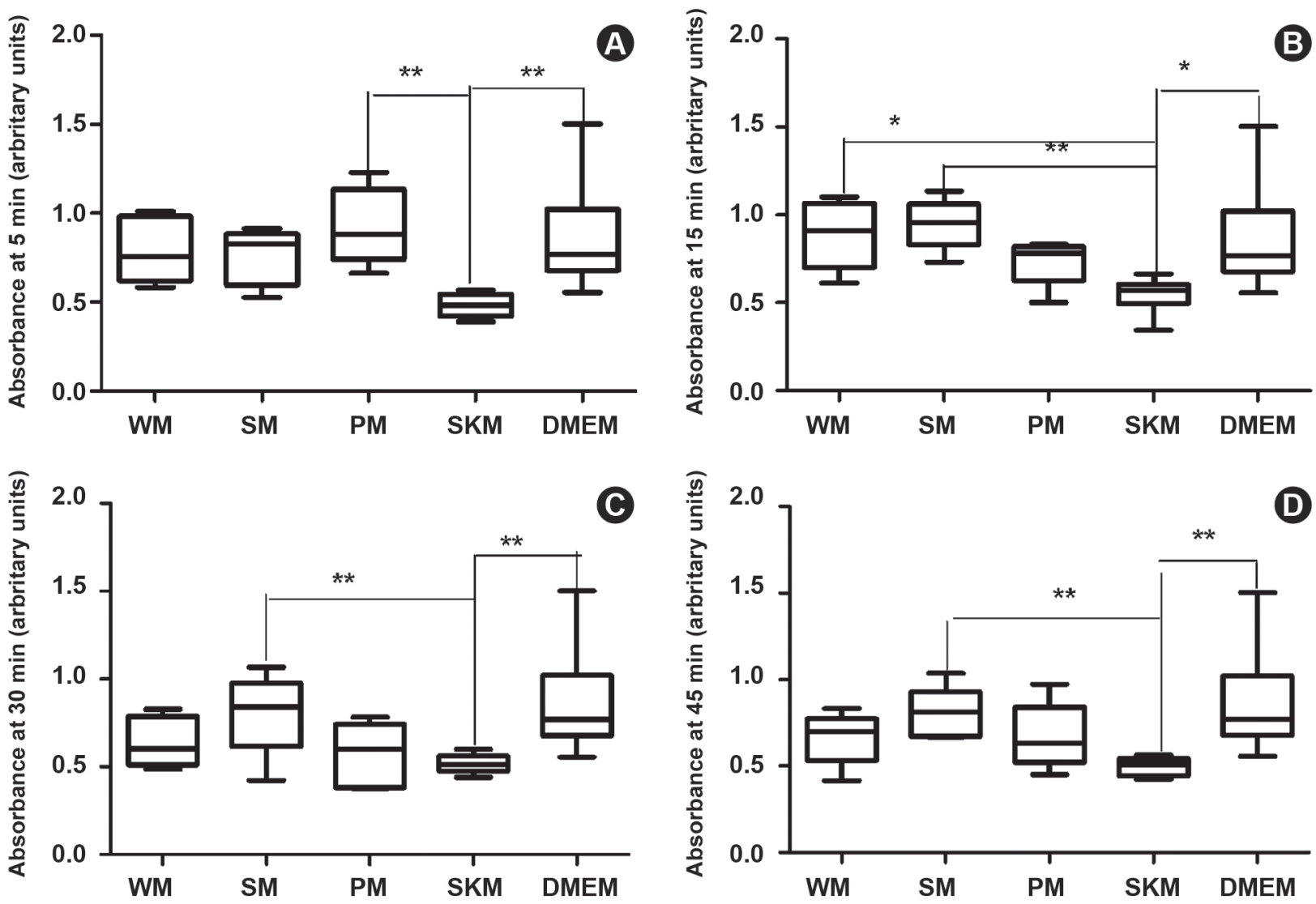

Figure 1. Comparison of absorbance values (cell viability) at 5 (A), 15 (B), 30 (C) and 45 (D) min. WM: long shelf-life whole cow milk. SM: soy milk. PM: powdered cow milk. SKM: long shelf-life skim cow milk. DMEM: Control. ${ }^{* *}$ p $<0.01$. 
transportation of avulsed teeth.

Despite the interesting results found in the present study, considerations must be addressed regarding the methodologies used in in vitro studies to evaluate storage media for avulsed teeth $(2,10,24,25)$. Immortalized cell cultures, such as those used in this study, differ from primary cell cultures by their ability to proliferate indefinitely; thus, they have a different life cycle, which is a limitation. Experimental designs using newly extracted teeth, which simulate avulsion, should be carried out because they reproduce more accurately the clinical situation. However, we consider the model using extracted teeth as appropriated after the preliminary studies, which tend to be better designed with immortalized cells, as a way to validate the results. Thus, in vitro studies using immortalized cell cultures represent a complementary model to tooth models, with easy reproducibility, which justifies the choice of methods in this study.

Regarding the method used to evaluate cell viability, studies using trypan blue staining have shown less sensitivity because it does not characterize the metabolic condition of the cell or its actual physiological health (2). In this way, an MTT assay should be a more sensitive tool for cell viability analysis than trypan blue staining (4). Considering that the relative opacity of milk may interfere in optical density reading (4), after exposure to milk, the wells were washed twice with PBS and filled with fresh medium to avoid interference in the optical readings.

Studies have demonstrated that time can influence the effectiveness of different storage media $(1,4,11)$. The time over which cell viability is preserved in milk is controversial (4). The present study used time periods (from 5 to $45 \mathrm{~min}$ ) because this allowed monitoring small changes over time. At the evaluated times, WM, PM and SM stored at room temperature showed a similar capacity to preserve human gingival fibroblasts. However, what drew most attention in this study were the results for the SM and SKM. While the former was similar to the positive control at all experimental times, the latter was significantly less effective than the control group (DMEM). Further in vitro and in vivo studies should be conducted with variable dry periods and longer storage times to determine the capacity of SM for storage of the avulsed teeth.

The favorable results obtained in this preliminary study suggest that SM might be a promising alternative medium for transportation of avulsed teeth. In contrast,
SKM tends to be not adequate as a storage medium for avulsed teeth.

\section{RESUMO}

O leite de soja (LS) é largamente consumido em todo o mundo como substituto para o leite bovino. Este é uma fonte de vitaminas, carboidratos e açúcares, mas a sua capacidade para preservar a viabilidade celular não foi avaliada. A finalidade do estudo foi investigar a eficácia do LS em manter a viabilidade de fibroblastos humanos em períodos curtos em comparação com diferentes leites bovinos. Fibroblastos de boca humanos foram cultivados e armazenados nos seguintes meios à temperatura ambiente: 10\% de meio Dulbecco's Modified Eagle (DMEM) (grupo controle positivo); leite bovino integral longa vida (LI); leite bovino desnatado longa vida - LD; leite em pó - LP; leite de soja - LS. Depois de 5, 15, 30 e $45 \mathrm{~min}$, a viabilidade celular foi analisada usando o método de MTT. Os dados foram analisados estatisticamente pelo teste de Kruskal-Wallis e posteriormente usando o método de Dunn $(\alpha=0,05)$. O grupo LD apresentou a menor capacidade para manter a viabilidade celular em todos os tempos analisados $(\mathrm{p}<0,05)$. Aos 30 e aos 45 min, os níveis de absorbância no grupo controle (DMEM) e LS foram significativamente maiores que no grupo $\operatorname{LD}(\mathrm{p}<0,05)$. A viabilidade celular diminuiu ao longo do tempo (5-45 $\mathrm{min}$ ). Os resultados indicaram que LS pode ser usado como meio de armazenamento mais adequado para dentes avulsionados. LD não foi eficaz na preservação da viabilidade das células como o meio de cultura de células e o LS.

\section{REFERENCES}

1. Andersson L, Bodin I. Avulsed human teeth replanted within 15 minutes - a long-term clinical follow-up study. Endod Dent Traumatol 1990;6:37-42.

2. Rajendran P, Varghese NO, Varughese JM, Murugaian E. Evaluation, using extracted human teeth, of Ricetral as a storage medium for avulsions - an in vitro study. Dent Traumatol 2011;27:217-220.

3. Trope M. Avulsion of permanent teeth: theory to practice. Dent Traumatol 2011;27:281-294.

4. Souza BDM, Lückemeyer DD, Felippe WT, Simões CM, Felippe MC. Effect of temperature and storage media on human periodontal ligament fibroblast viability. Dent Traumatol 2010;26:271-275.

5. Mori GG, Janjacomo DMM, Nunes DC, Castilho LR. Effect of zoledronic acid used in the root surface treatment of late replanted teeth: a study in rats. Braz Dent J 2010;21:452-457.

6. Sigalas E, Regan JD, Kramer PR, Witherspoon DE, Opperman LA. Survival of human periodontal ligament cells in media proposed for transport of avulsed teeth. Dent Traumatol 2004;20:21-28.

7. Andreasen JO. Effect of extra-alveolar period and storage media upon periodontal and pulpal healing after replantation of mature permanent incisors in monkeys. Int J Oral Surg 1981;10:43-53.

8. Gopikrishna V, Thomas T, Kandaswamy D. A quantitative analysis of coconut water: a new storage media for avulsed teeth. Oral Surg Oral Med Oral Pathol Oral Radiol Endod 2008;105:61-65.

9. Gopikrishna V, Baweja PS, Venkateshbabu N, Thomas T, Kandaswamy D. Comparison of coconut water, propolis, HBSS, and milk on PDL cell survival. J Endod 2008;34:587-589.

10. Souza BD, Lückemeyer DD, Reyes-Carmona JF, Felippe WT, 
Simões CM, Felippe MC. Viability of human periodontal ligament fibroblasts in milk, Hank's balanced salt solution and coconut water as storage media. Int Endod J 2011;44:111-115.

11. Huang SC, Remeikis NA, Daniel JC. Effects of long-term exposure of human periodontal ligament cells to milk and other solutions. J Endod 1996;22:30-33.

12. Harkacz OM Sr, Carnes DL Jr, Walker WA 3rd. Determination of periodontal ligament cell viability in the oral rehydration fluid Gatorade and milks of varying fat content. J Endod 1997;23:687690.

13. Marino TG, West LA, Liewehr FR, Mailhot JM, Buxton TB, Runner RR, et al.. Determination of periodontal ligament cell viability in long shelf-life milk. J Endod 2000;26:699-702.

14. Pearson RM, Liewehr FR, West LA, Patton WR, McPherson JC 3rd, Runner RR. Human periodontal ligament cell viability in milk and milk substitutes. J Endod 2003;29:184-186.

15. Caglar E, Sandalli N, Kuscu OO, Durhan MA, Pisiriciler R, Caliskan EA, et al.. Viability of fibroblasts in a novel probiotic storage media. Dent Traumatol 2010;26:383-387.

16. Saxena P, Pant VA, Wadhwani KK, Kashyap MP, Gupta SK, Pant $\mathrm{AB}$. Potential of the propolis as storage medium to preserve the viability of cultured human periodontal ligament cells: an in vitro study. Dent Traumatol 2011;27:102-108.

17. Moreira-Neto JJ, Gondim JO, Raddi MS, Pansani CA. Viability of human fibroblasts in coconut water as a storage medium. Int Endod J 2009;42:827-830.

18. Blomlöf L. Milk and saliva as possible storage media for traumatically exarticulated teeth prior to replantation. Swed Dent J Suppl 1981;8:1-26.

19. Lindskog S, Blomlöf L. Influence of osmolality and composition of some storage media on human periodontal ligament cells. Acta Odontol Scand 1982;40:435-441.

20. Belford DA, Rogers ML, Regester GO, Francis GL, Smithers GW, Liepe IJ, et al.. Milk-derived growth factors as serum supplements for the growth of fibroblast and epithelial cells. in vitro Cell Dev Biol Anim 1995;31:752-760.

21. Moazami F, Mirhadi H, Geramizadeh B, Sahebi S. Comparison of soymilk, powdered milk, Hank's balanced salt solution and tap water on periodontal ligament cell survival. Dent Traumatol 2012;28:132-135.

22. Chamorro MM, Regan JD, Opperman LA, Kramer PR. Effect of storage media on human periodontal ligament cell apoptosis. Dent Traumatol 2008;24:11-16.

23. Dos Santos CL, Sonoda CK, Poi WR, Panzarini SR, Sundefeld ML, Negri MR. Delayed replantation of rat teeth after use of reconstituted powdered milk as a storage medium. Dent Traumatol 2009;25:51-57

24. Patel S, Dumsha TC, Sydiskis RJ. Determining periodontal ligament (PDL) cell vitality from exarticulated teeth stored in saline or milk using fluorescein diacetate. Int Endod J 1994;27:1-5.

25. Lekic P, Kenny D, Moe HK, Barretti E, McCulloch CA Relationship of clonogenic capacity to plating efficiency and vital dye staining of human periodontal ligament cells: implications for tooth replantation. J Periodontal Res 1996;31:294-300.

Received April 13, 2012

Accepted September 26, 2012 